\title{
AN INF ORMATION DATA BASE OF GEODETIC SERVICES ENGINEERING INVESTMENTS - THE IDEA OF DATA ORGANISATION INFORMATIV $\bar{A} S$ B $\overline{A Z E S ~ K O N C E P C I J A S ~ R A D I ̇ S ~ A N A ~}$ INŽENIERTEHNISKO INVESTICCIJU GEODËZISKO VAJADZĪBU APKALPOŠANA
}

\section{JANINA ZAC ZEK-PEPLINSKA, R YSZARD KOW ALSKI}

\author{
Institute of Applied Geodesy, Warsaw University of Technology, Plac Politechniki 1, \\ 00-661 Warsaw, Poland, e-mail: j.peplinska@gik.pw.edu.pl
}

\begin{abstract}
The goal of the project, being run by the Institute of Applied Geodesy of the Warsaw University of Technology, is to create a prototype database of building structures, which are typical from the point of view of the tasks of engineering geodesy.

The database is expected to be available through the Internet and is planned to be filled with the information collected from surveying companies, which would like to present their realizations both from owners and users of engineering structures.

Examples of modern solutions in the area of geodetic services for engineering investments realization is supposed to create a base for changes in the methods of teaching and presenting these issues at the Faculty of Geodesy and Cartography of the Warsaw University of Technology and at other Faculties interested in such problems.

Keywor ds: geoinformation, Land Information System (LIS), engineering-industrial geodesy, investment's realization, geodetic documentation.
\end{abstract}

\section{Introduction - Geodetic services of investments}

High diversification of tasks, which can be faced by a surveyor, is specific for engineering geodesy. Particular objects require that specific geometric conditions are met in the course of their implementation and that control of those conditions is often performed in the period of exploitation. Implementation networks, which are set in order to perform geodetic services, must be usually adapted to requirements of an object, with respect to their shapes and accuracy. Methods of setting out detailed points, as well as of control measurements, must be adapted to conditions of the task implementation. Limited time of access to an object, operations performed in poor illumination, increased temperature, or vibrations of the instrument foundations, often require untypical measurement methods. At the same time, those methods must be adapted with respect to their accuracy - to requirements of the Project or to requirements settled with contractors of building works.

Geodetic services of investments consist of a set of operations performed at the stages of predesign studies, technical design and investment implementation, as well as in the course of object measurements during exploitation of objects [4].

\section{The data issue}

\section{Diversification of works included in the geodetic services of investments.}

In practice, every task of engineering geodesy connected with a particular building object and technology of geodetic works, related to implementation of such an object, must be adapted to the object requirements. On the other hand, independently on the type of an object, successive stages of geodetic works may be distinguished for every task; those works are performed following obligatory standards specified by legal norms, which regulate the rules of implementation of geodetic works [5]; (Fig.1).

The scope of works which include geodetic services of investments (which often consist of many engineering objects) must be always compliant with corresponding technical and legal regulations and it should be enlarged by certain elements, depending on characteristic features of the given objects and on expectations of the investor. For many typical building objects and 
engineering constructions rules concerning the surveyor's participation in the process of investment implementation are regulated in details by various legal acts, sectoral norms, as well as by surveying instructions and guidelines. On the other hand, detailed solutions must be adapted to conditions of implementation of typical objects.

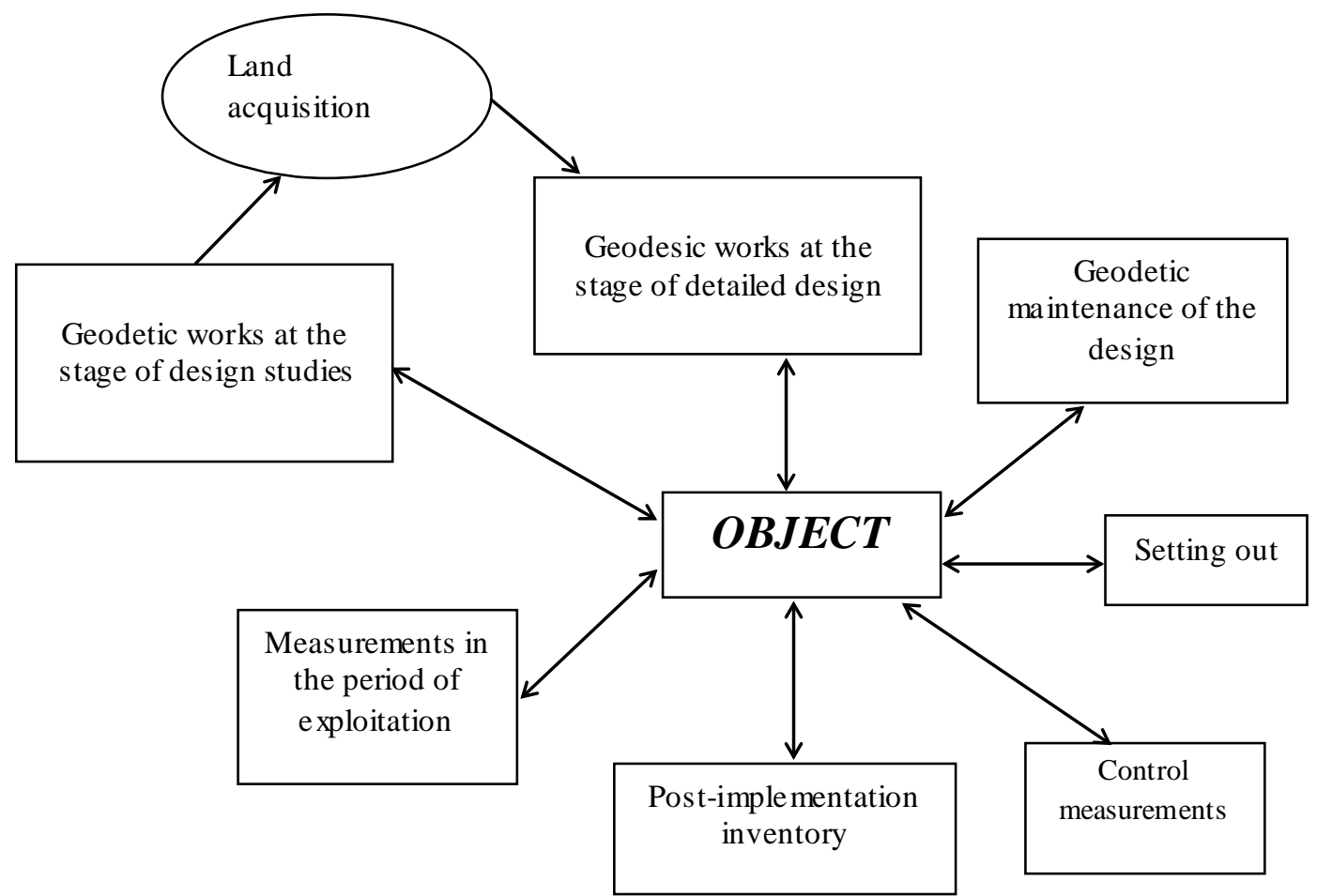

Fig. 1. Ele ments of geodetic services of engineering investments

Implementation of engineering geodesy tasks and their reporting in technical documentation. In the natural way geodesy is understood as the main technical domain which is specialised in acquisition, processing and distribution of land information. Basing on resources from state archives (in Poland: Geodetic-and-Cartographic Documentation Centres) various national and regional land information systems are created, being the main databases used for the needs of implementation of investment processes.

Engineering geodesy is one of the active users of spatial information and, at the same time, it delivers information for data updating.

Specific tasks, which should be solved by an engineering surveyor, may include the necessity to produce appropriately documents at all stages of the works. Each surveyor's operation is reflected in technical documentation which is developed before (as setting out sketches), as well as in the course of (field sketches and logs) and after completion of the given stage of works (as calculations, analyses and maps). Every developed document is related to an object which is located within the particular area.

The Land Information System (LIS, SIT in Polish) is understood as a supportive tool for the process of making economic decisions as well as the support in planning processes; it is also one of the basic data sources (beside information acquired during updating measurements), which are used for development documentation for designing purposes [1];(Fig. 2).

A good example is a map used for designing purposes; in the course of waiting for an investor such a map is supplied with geo-spatial data from various sectors related to geography, natural environment, city technical infrastructure etc. (Fig. 3).

The base map and the topographic map exist in the social awareness as products of geodesy and cartography and - following legal regulations - they are used to meet various economic requirements. It should be noticed that users of such maps include not only designers, urban planners, road construction specialists or experts for spatial management; such maps are mainly used by surveyors, who are often agents operating between the data resources and the data user. 
The task of surveyors dealing with geodetic services for investments is to acquire land information in a form required for implementation of particular designs.

Therefore, the database concerning geodetic services for engineering objects, which comprises surveying documentation, should be considered as support in searching for data required for preparation of geodetic works.

Updated information about the resources as well as suggestions concerning possible ways of reaching the data and utilisation of acquired information will considerably support operations of contractors. Beside surveyors, such information will be also used by architects, environmental engineers, geologists - all specialists who use such data for their work.

\section{Base of information on geodetic services for engineering investments.}

In the case of many objects and constructions the resources of land information, which are by obligation acquired and stored in the national system, are not sufficient; detailed sectoral regulations require that the surveyor must acquire various auxiliary information. The question arises whether the information must be collected every time for particular designs or it would be cheaper and easier to develop a system of storing such data.

Geodetic services for a building object are usually completed with post-implementation inventory, which should meet two objectives - apart from controlling the compliance between the implementation and the design: it should allow for updating the Land Information System and it should ensure acquisition of geometric information about the location and shape of the implemented object, which result from sectoral regulations.

It may be generally stated that at the stage of data preparation for the design, as well as in the course of post-implementation measurements, engineering geodesy acquires many information which may be specified as geodetic inventory of building objects. Therefore, some questions arise whether information of this type is useful for generally understood economic purposes and whether it can exist in national archives, as well as how it should be delivered to those archives and what should be covered by such information. The objectives of the Project performed at the Laboratory for Engineering-and-Industrial Geodesy of the Institute of Applied Geodesy of the Warsaw University of Technology is to create an example information base concerning building objects, which are characteristic from the point of view of tasks of engineering geodesy.

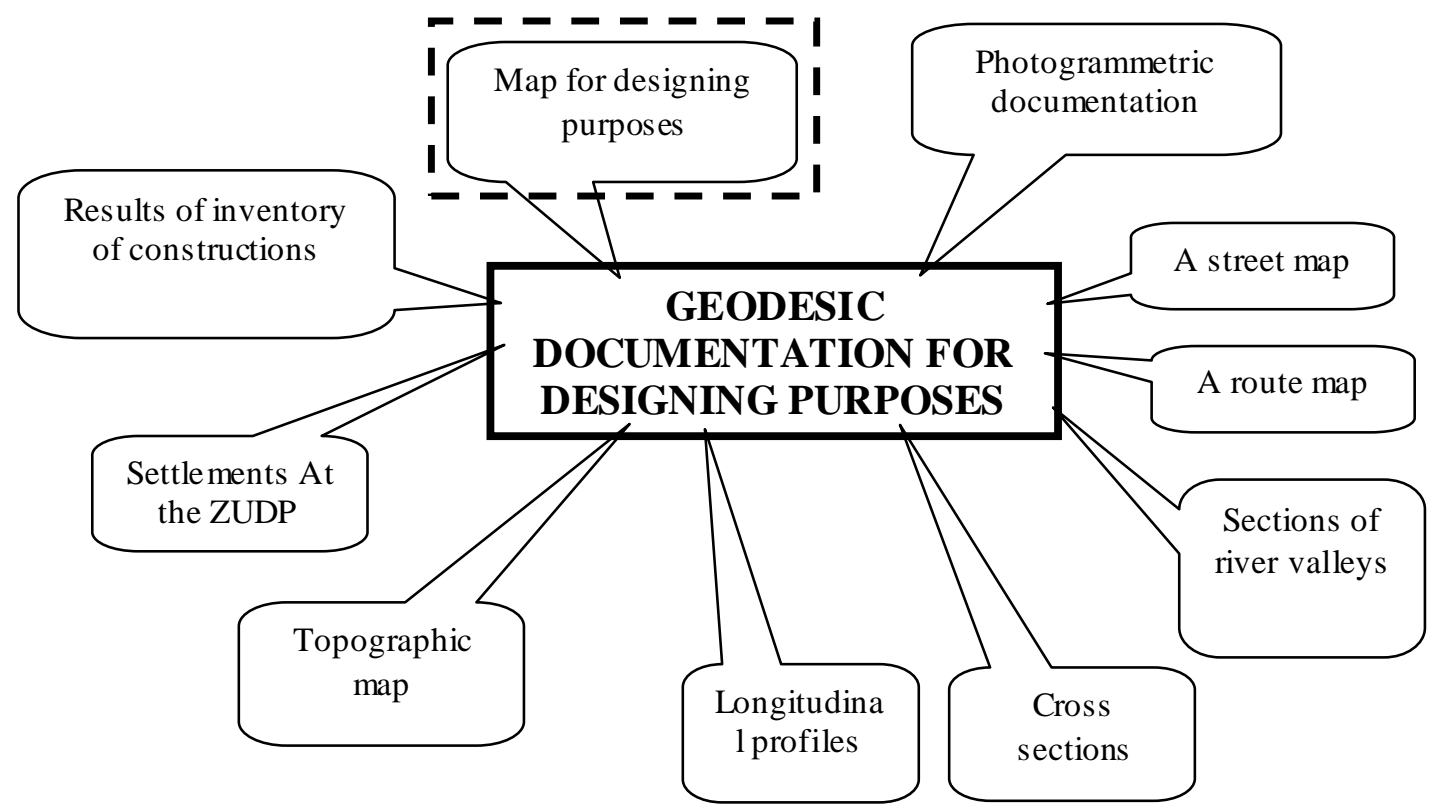

Fig. 2. Complexity of geodetic docume ntation for designing purposes

\section{Definition of information in the context of services for investments.}

From the engineering geodesy point of view, the most important features of the object are geometric relations between its elements and location of an object in the space. Location and technical requirements concerning the object geometry (resulting from its functions and 
exploitation expectations of an investor) are elementary data required for the design implementation - definition of a set of geometric features, such as: verticality, parallelism of axes or collinearity of constructional elements [4]. To a certain extent, complexity of those features forces the appropriate sequence of implementation of geodetic works, and documentation, which is developed at every stage of works performed by the surveyor, should be coherent and it should be the base for successive operations. Geometric features of the object, measuring technology and documentation cannot be considered separately - therefore, the information unit included in the information data base concerning geodetic services form engineering investments have been defined as a series of operations, which is started with the design and completed with development of geodetic documentation of geodetic services, characteristic for the given stage [2]; (Fig. 4).

\section{A suggestion to solve the problem}

\section{A concept of the information data base organization.}

The concept described below was the basis for implementation of a prototype database - the Database on Geodesic Services for Investments (BIGOS) [2]. The database, which was developed at the Institute of Applied Geodesy of the Warsaw University of Technology has not been populated with real data yet; all data concerning engineering objects, elements of geodetic services and related documentation are used only for testing the correctness of implementation of searching algorithms and functionality of the user interface.

The engineering object, such as a chimney, a lift shaft, an overpass, a building, a bridge or a tunnel is defined with a series of features which describe its nature. Those features have been divided into four groups:

- $\quad$ Objective of implementation (eg. to by-pass a roadblock, to ensure roof coverage),

- $\quad$ A system (eg. high, linear, underground, surface),

- $\quad$ Functions (eg. transport, housing, industrial),

- Geometry - geometric features, which are implemented in the course of geodetic services and controlled in the course of the object exploitation (eg. rectilinearity, perpendicularity, verticality).

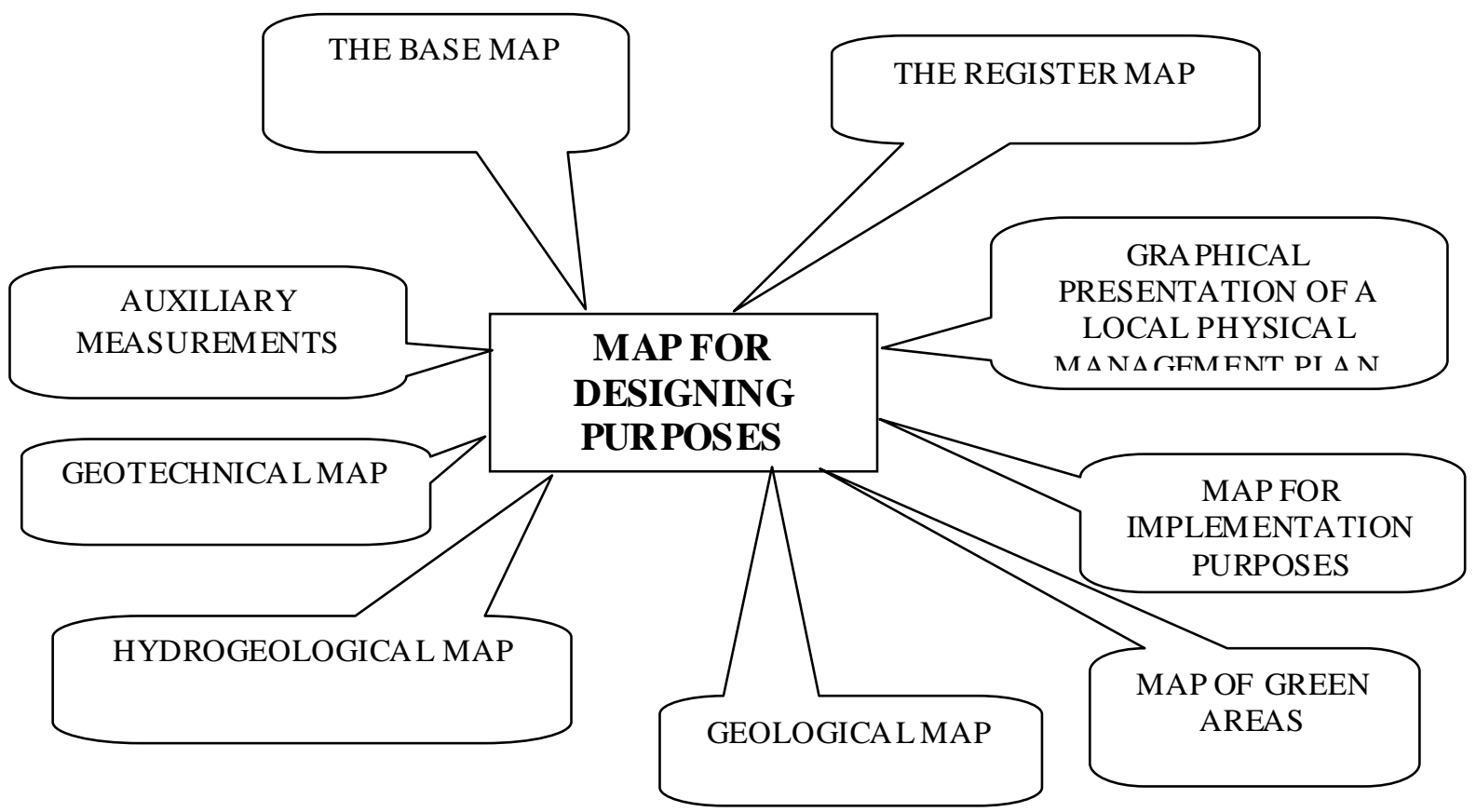

Fig. 3. Examples of information sources used for development of a map for designing purposes 


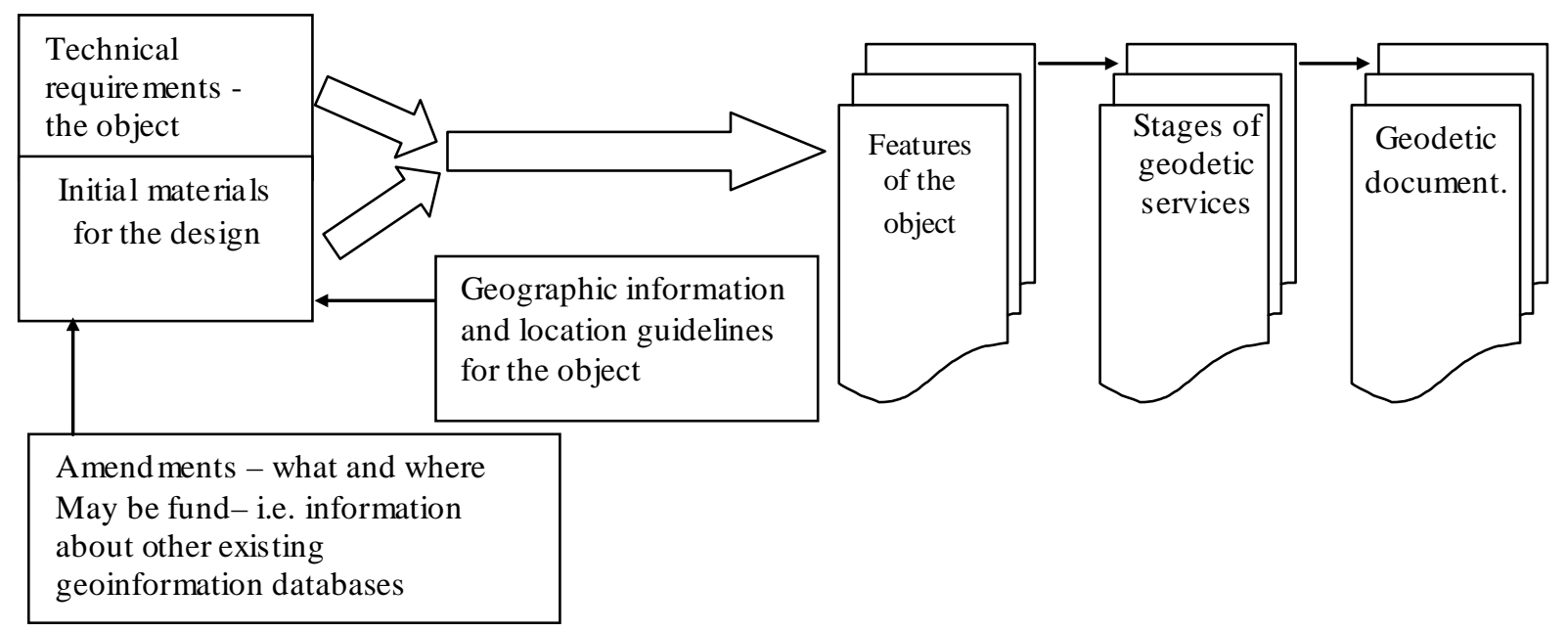

Fig. 4. Information unit concerning geodetic services for investments

Table 1.

An example of an object definition

\begin{tabular}{|c|c|c|c|c|}
\hline \multirow[b]{2}{*}{ OBJECT } & \multicolumn{4}{|c|}{ FEATURES } \\
\hline & $\begin{array}{l}\text { Implementation } \\
\text { objectives }\end{array}$ & System & functions & geometry \\
\hline $\begin{array}{l}\text { Water } \\
\text { dam }\end{array}$ & $\begin{array}{l}\text { - water damming up, } \\
\text { - water supply, } \\
\text { - power production, } \\
\text { - flood protection }\end{array}$ & $\begin{array}{l}\text { - linear, } \\
\text { - high }\end{array}$ & $\begin{array}{l}\text { - industrial, } \\
\text { - transport }\end{array}$ & $\begin{array}{l}\text { - rectilinearity, } \\
\text { - maximum height }\end{array}$ \\
\hline
\end{tabular}

Lists of features are "open" dictionaries which will be enlarged by introducing new objects to the database, described in a way that ensures its explicit identification. Explicit features do not exclude the possibility to meet a certain condition by a group of similar objects.

Those features are reflected in a technical design, which is developed basing on the investor's "idea" and technical-and-legal, as well as geospatial information connected with the spatial location of the given object. Basing on all mentioned above objects are defined in the design.

Geometric features of the object are implemented in appropriate stages of geodetic services, which - apart from implementation of field works (measurements, setting out) - result in geodetic documentation (Fig. 5).

The scope of presentation of information stored in the database depends on a way of searching. An engineering object may be accessed in the database by selecting this object from a list of objects defined in the database or by searching for objects with a specific geometric features or such objects, which require that a specified stage of geodetic services is performed.

Due to the outstanding role of geodetic documentation in the process of investment implementation, as well as considering its complexity and repeatability at various stages of services (a good examples are a sketch and its various types: a field sketch, a setting out sketch, a network sketch, a documentation sketch etc.), it is possible to search for objects in the database basing on previously defined elements of geodetic services as well as on types of documents. Geodetic documents will be presented and described in the database basing on particular examples related to engineering objects, introduced to the database.

Searching for engineering objects, and thus interesting elements of geodetic services and related documentation, is performed by means of creation of "and" or "or" conditions. 


\section{Stages of geodetic services in BIGOS System.}

Description of geodetic works performed in the course of the object implementation and developed documents, is the basic information included in the database. Therefore, the general division of geodetic works performed within services for the investment, is very important. After long discussions held at the Institute of Applied Geodesy, the following division of geodetic works into particular elements of geodetic services has been approved:

$\underline{0 .}$ Cartographic materials (acquired for designing and location purposes)

\section{At the designing stage}

1. A map for designing purposes,

2. A longitudinal profile of the area,

3. A cross section of the area,

4. A digital elevation model,

5. Auxiliary surveys.

II. At the stage of location setting out

1. A documentation sketch,

2. A horizontal implementation network,

3. A vertical implementation network (operating benchmarks),

4. A sketch of setting out main axes,

5. Control of setting out.

III. At the stage of detailed setting out

1. A building and assembly network (a local implementation network),

2. A sketch of setting out,

3. A sketch of control of setting out,

4. Control measurements of an element positioning,

5. Measurements of verticality of an element,

6. Measurements of flatness,

7. Control of dimensions,

8. Control of shapes.

IV. Post-implementation inventory

1. The base map updating,

2. Inventory underground installations,

3. Control of rectilinearity,

4. Control of verticality,

5.Control of expansion of constructional axes,

6.Post-implementation inventory of a roadway,

7. Control of settlements of a bridge (an overpass) plate.

V. Control measurements in the exploitation phase

1.Measurements of dislocations

2. Control of stability of geometric conditions.

The above list is the initial content of the dictionary of „elements of geodetic services” implemented in the database; it may be expanded and modified according to existing needs.

\section{Functionality of the Geodesic Services Information Base (BIGOS).}

Since the Information Base is to be finally accessible in the Internet, its user interface should be readable and user friendly. The operating path has been designed in such a way that windows containing various information may be simultaneously viewed, provided that the sequence order of access to particular elements of an information unit is maintained:

$\Rightarrow$ WYBRANY OBIEKT (SELECTED OBJECT) (Description, features and information concerning elements of services and documentation defined in an object), 
or

$\Rightarrow$ ELEMENT OBSŁUGI GEODEZYJNEJ (ELEMENT OF GEODETIC SERVICES) (Description and a list of related documents),

$\Rightarrow$ DOKUMENT (DOCUMENT)

$\Rightarrow$ WYBRANY OBIEKT (SELECTED OBJECT) (Description, features and information concerning elements of services and documentation defined in an object),

$\Rightarrow$ RODZAJ DOKUMENTU (DOCUMENT TYPE) (Description and a list of documents of a selected type),

$\Rightarrow$ DOKUMENT (DOCUMENT).

Each of selected documents is presented in a separate window, what allows the user to develop the customized screen composition and selection of documents and descriptions for further comparisons.

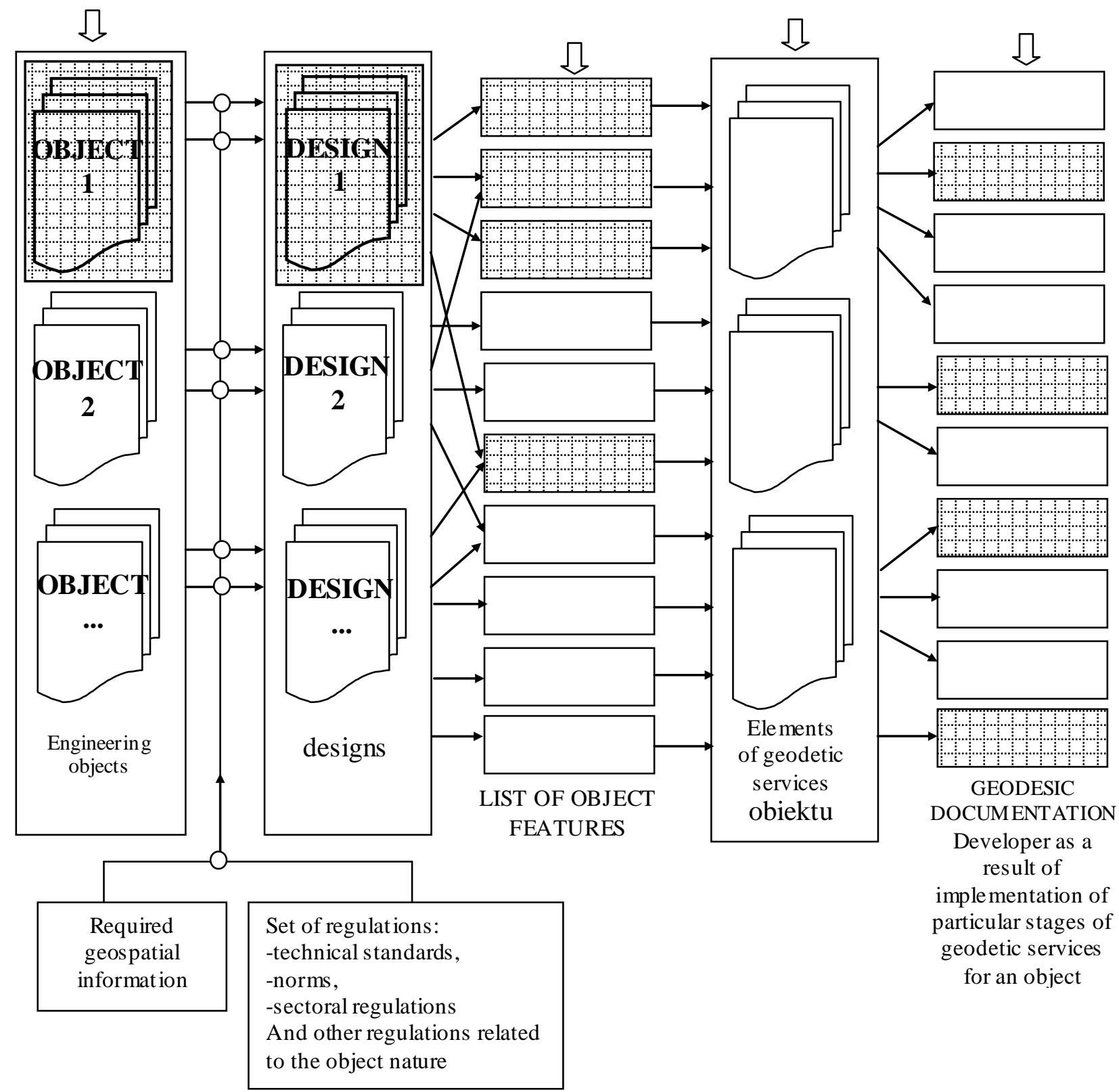

Fig. 5. Organisation of the information base 


\section{Acquisition, distribution and utilization of data.}

The information data base concerning geodetic services for investments will be supplied with information acquired from surveying companies, which are interested in presentation of their achievements, as well as from geospatial database providers (with respect to specification „what” and „where”) and from owners and users of engineering objects. We also look forward to cooperation with state archives (Geodesic and Cartographic Documentation Centres) as well as with technical control units [6]. It seems to us that such a database, containing examples of digital-and-graphical works for various objects, may be also the source of knowledge, presenting ways of proper preparation of technical documentation.

Examples of modern solutions in the field of geodetic services for implementation of engineering objects should also be the basis for modifications of education curricula and presentation of those issues at the Faculty of Geodesy and Cartography of the Warsaw University of Technology as well as at other faculties [3], which are interested in those topics.

The discussed database is to be finally accessible in the Internet - in the first phase mainly as presentation of complexity of engineering-and-industrial geodesy. In the future it will become a tool delivering information for didactic purposes, being also an inspiration for specialists dealing with engineering geodesy.

\section{Conclusions}

When completed, the database concerning geodetic services for engineering investments, may become the aid for didactic works at universities, which run studies in the field of geodesy, as well as it may be the aid for practicing surveyors in their professional operations.

At present, the main reasons for creation of such a database may be listed as follows:

1. for didactic and training purposes - presentation (in a widely accessible way) of implemented projects concerning geodetic services for various investments may be supportive for permanent development of professional qualifications of surveyors practitioners,

2. in order to popularise knowledge concerning the importance and the role of surveying in the process of investment implementation among specialists from involved sectors,

3. in order to promote unified standards,

4. for university education needs, in order to create an accessible information base concerning ways of implementation of works in the field of engineering-and-industrial geodesy.

Appropriate visualisation of data stored in the database and distribution of his data among wide groups of interested individuals may result in popularisation of engineering geodesy and, thus, it may contribute to wider presentation of surveying companies, which were involved in implementation of presented engineering investments.

\section{References}

1. Gaździcki J. „Systemy informacji przestrzennej” (Spatial Information Systems) , PPWK , WarszawaWrocław 1990;

2. Kowalski R., Zaczek-Peplinska J. „Koncepcja utworzenia bazy informacji o geodezyjnej obsłudze inwestycji inżynierskich" (A concept of creation of the information base concerning geodetic services for engineering investments), Roczniki Geomatyki 2004, Tom II, Zeszyt 2;

3. Olenderek H., Parzyński Z., „Stan i perspektywy rozwoju edukacji w dziedzinie geomatyki” (Status and perpectives of educational development in the field of geomatics), Materiały XII Konferencji NaukowoTechnicznej „Systemy Informacji Przestrzennej”, Warszawa 2002;

4. Praca zbioro wa „Geodezja inżynieryjna” (Engineering Geodesy), PPW K, Warszawa-Wrocław 1989;

5. Instrukcja techniczna G-3 „Geodezyjna obsługa inwestycji” (Geodetic services for investments), wydanie III, GUGiK, Warszawa 1989;

6. Instrukcja techniczna O-3/O-4 „Prowadzenie Państwowego Zasobu Geodezyjnego i Kartografic znego oraz kompletowanie dokumentacji prac geodezyjnych i kartograficznych” (Technical Instruction O-3/O-4 "Maintenance of the State Geodetic and Cartographic Resources and collection of documentation of surveying and cartographic works”), GUGIK, 2001. 